\title{
Türk Hukukunda Kamu Görevlileri Sendikalarının Kuruluş ve Örgütlenmesi
}

\author{
Establishment and Organization of Public Servants Trade Unions in \\ Turkey
}

\author{
Hakan CINDEMIR*
}

\begin{abstract}
Özet
Demokratik ülkelerde kamu görevlileri dahil çalışanların tamamına tanınan ve bir insan hakkı olan sendika hakkı ülkemizde de kamu görevlilerine tanınmıştır. 4688 sayılı kanunda 2012 yılında yapılan değişikliklerle Türk hukukunda kamu görevlilerinin sendikacılığ önemli bir değişime uğramıştır. Bu doğrultuda kamu görevlilerinin sendikalarının kuruluş ve yapısı da önemli ölçüde değişmiştir. İş bu çalışmada öğretide çok sınırlı bir şekilde incelenmiş olan söz konusu değişiklikler ve Türk hukukunda kamu görevlileri sendikalarının kuruluş ve yapısında gelinen son nokta incelenmiştir. Bu bağlamda, öncelikle 6289 sayılı kanunla kamu görevlileri sendikalarının kuruluş ilkelerinde meydana gelen değişimler incelemiştir. Yine bu ilkeler doğrultusunda kamu görevlileri sendikalarının kuruluş şartları, kurucularda aranan şartlar ve üyelik hakkı incelenmiştir. Özellikle kamu görevlileri sendikalarına üye olamayacaklarla ilgili olarak ulusal ve uluslararası yargı organları kararları doğrultusunda gelinen son nokta ve eksiklikler ortaya konulmuştur. Son olarak yeni mevzuat doğrultusunda üyelerin hak ve borçları ortaya konulmuştur.
\end{abstract}

Anahtar Kelimeler : Türk Hukukunda Kamu görevlileri sendikacılığı, Türk Hukukunda Kamu görevlileri sendikalarının kuruluşu. Kamu görevlilerinin Örgütlenmesi., 4688 sayılı kanun, 6289 sayılı kanun

\begin{abstract}
Democratic states granted trade union rights to all employees, including public officials. Turkey is one of these countries, which granted trade unions rights to public officials. With the amendments made in 2012 in the law no. 4688 , the trade unionism of public officials in Turkish law has changed significantly. The organization and structure of public employees unions have also changed significantly. This study examines the changes in the establishment and structure of the unions of public officials in the Turkish law. In this context, changes made by the law no 6289 on the founding principles of trade unions are examined in the first hand. With these principles, we examined the conditions of the membership, the requirements for the founders and the right for membership of the public service unions. Finally the rights and obligations of the members and the officers who are ineligible to become member are examined through the national and international jurisdictions.
\end{abstract}

Keywords : Trade unions of public servants in Turkey, Establishment and organization of public servants' trade unions in Turkey' Establishment and organization of pulic officers' syndicates

\section{Giriş}

Sendikal hakların bütün çalışanlar için bir insan hakkı olduğu bilincinin yerleşmesi ve bu hakkın uluslararası belgelerde de yer alması çok uzun ve tartışmalı bir süreç sonrasında olmuştur. Başlangıçta devletin özel yurttaşı olarak görülen ve bu nedenle güvence ve yasakları ile özel statüye bağlamış olan kamu görevlilerinin, bu özel statüleri nedeniylede örgütlenmeleri devlet tarafından uzun yıllar boyunca engellenmiştir. Bu süreçte işçi hakları gelişirken, önceleri az sayıda olmaları nedeniyle devlete ait bir çok yetkiye, ekonomik güce ve olanağa sahip olan kamu görevlilerininse sayılarının da artması sebebiyle haklarında zaman içerisinde gerilemeler meydana gelmiştir. Bu durum kamu görevlilerinin örgütlenmesine ve devletten topluca istekte bulunma hakkını aramaya yöneltmiştir. Devlet tarafından kamu görevlilerinin sendikal haklarına yönelik olarak yapılan engellemeler, kamu görevlerinin sendikal örgütlenmelerini geciktirmiş ve sendikalarının işçi sendikalarından farklı gelişimine sebebiyet vermiştir. Yirminci yüzyılın ikinci yarısından itibaren özellikle uluslararası belgelerde sendikal hakların kamu görevlilerine bütün kapsamıyla tanınmasıyla birlikte ulus devletler tarafindan kabul

\footnotetext{
* Dr., Öğretim Görevlisi, Gaziantep Üniversitesi, Hukuk Fakültesi, hakancindemir@yahoo.com.
} 
edilen yasakçı anlayış yerini kamu görevlileri açısından yeni ve özgürlükçü bir anlayışa bırakmıştır.

Çoğulcu esaslara dayalı çalışma hayatının önemli göstergelerinden biri olarak kabul edilen sendikal haklar, bir ülkede demokrasinin ne ölçüde gelişmiş olduğunu ortaya koyan önemli ölçütlerden biridir. Sendikal hakların gelişmiş olduğu ülkelerde demokrasi de en güçlü dayanaklarından birisini bulmuş demektir. Bu sebeple günümüzde demokratiklik iddiası ve ideali olan bir ülkede, çalışanların önemli bir bölümünü oluşturan kamu görevlilerinin sendikal haklardan yoksun bırakılması düşünülemez. Bu doğrultuda 1982 Anayasasında yapılan 1995 değişiklikleriyle Türk hukukunda uzun bir aradan sonra kamu görevlilerinin sendikal hakları tekrar tanınmıştır. Söz konusu Anayasal değişiklik doğrultusunda 4688 sayılı Kamu Görevlileri Sendikaları kanunu kabul edilmiştir. 4688 sayılı kanun, 2012 yılında 6289 sayılı kanunla önemli ölçüde değişikliğe uğramıştır. Bu bağlamda kamu görevlileri sendikalarının kuruluş şekli ve örgütlenmesi değiştirilmiş olup tekrar ayrıca inceleme zorunluluğu hasıl olmuştur.

\section{Kuruluş Esasları}

Kamu görevlileri sendikalarının kuruluş esasları ve organları Kamu Görevlileri Sendikaları ve Toplu Sözleşme Kanunu'nun ikinci kısmında düzenlenmiş olup, işçi ve işveren sendika ve konfederasyonlarının kuruluşunda olduğu gibi kamu görevlileri sendika ve konfederasyonları açısından da serbest kuruluş sistemi kabul edilmiştir. Yasanın 6/1 hükmünce sendika ve konfederasyonlar önceden izin almaksızın serbestçe kurulurlar (Turhan, Gümrükçüoğlu ve Bozkurt 2014).

Kamu Görevlileri Sendikaları ve Toplu Sözleşme Kanunu sendika kuruluş esasları açısından hizmet kolu esasına göre sendikalaşmaya izin vermiştir. 4. maddeye göre "Sendikalar hizmet kolu esasına göre, Türkiye çapında faaliyette bulunmak amacıyla bir hizmet kolundaki kamu işyerlerinde çalışan kamu görevlileri tarafından kurulur. Meslek veya işyeri esasına göre sendika kurulamaz". Görüldüğü gibi kamu görevlileri sendikaları açısından sendikaların güçlü yapılanmalarına olanak sağlanması amacına uygun olarak meslek ve işyeri esasına göre sendikalaşma açık bir şekilde yasaklanmış olup; hizmet kolu esası çerçevesinde Türkiye çapında faaliyette bulunma amacıyla kurulma zorunlu kılınmıştır ( Sur, 2015). Gerçi Türkiye çapında faaliyette bulunma koşulu sendikanın fiilen Türkiye çapında örgütlenmiş olması değil, Türkiye çapında örgütlenmeyi amaç edinerek tüzüğünde bu hususa yer vermiş olmasıdır ( Tuğ, 1992).

Kanunun 5. maddesi ise hizmet kollarını: 1. Büro, bankacılık ve sigortacılık hizmetleri, 2.Eğitim, öğretim ve bilim hizmetleri, 3. Sağlık ve sosyal hizmetler, 4. Yerel yönetim hizmetleri, 5. Basın, yayın ve iletişim hizmetleri, 6. Kültür ve sanat hizmetleri, 7. Bayındırlı, inşaat ve köy hizmetleri, 8. Ulaştırma hizmetleri, 9. Tarım ve ormancılık hizmetleri, 10. Enerji, sanayi ve madencilik hizmetleri ve 11. Diyanet ve vakıf hizmetleri olarak belirlemiştir. Kamu işyerlerinin girdikleri hizmet kolları ise bu maddeye dayanılarak çıkarılan Kamu Görevlileri Sendikaları Kanununun Kapsamına Giren Kurum ve Kuruluşların Girdikleri Hizmet Kollarının Belirlenmesine İlişkin Yönetmelik'te gösterilmiştir. Yönetmelik uyarınca kamu kurum ve kuruluşlarının girdikleri hizmet kolunda anlaşmazlık çıkması halinde hizmet kolu yürütülen görevin niteliğine göre Çalışma ve Sosyal Güvenlik Bakanlı̆̆g, Maliye Bakanlığı ve Devlet Personel Başkanlığınca birlikte belirlenecektir. Yönetmeliğin yürürlüğe girmesinden sonra kurulacak kamu kurum ve kuruluşlarının dahil edileceği hizmet kolu ise yine Maliye Bakanlığı, Çalışma ve Sosyal Güvenlik Bakanlığı ve Devlet Personel Başkanlığınca tespit edilecektir.

Gerek hizmet kollarının kanun da sayılması ve gerek işyerlerinin hangi hizmet kollarına dahil olduklarının tespit edilmiş olması kanun tekniğine uygun bir düzenleme olarak görülebilirse de bu anlamda en önemli eksiklik bir işyerinin hangi hizmet koluna girdiğine ve hizmet kolu istatistiklerine yönelik itiraz usulüne ilişkin olarak herhangi bir hükme yer 
verilmemiș olmasıdır. Mevcut boșluğun ortadan kaldırılması maksadıyla Yasanın 43. maddesinde "Bu Kanunda hüküm bulunmayan hallerde 2821 sayılı Sendikalar Kanunu, 2908 sayılı Dernekler Kanunu, 743 sayılı Türk Medeni Kanunu ile sendika ve konfederasyonlarda görev alacaklar hakkında kamu görevlilerinin tabi oldukları personel kanunlarının ilgili hükümleri uygulanır" düzenlemesine yer verilmiştir.

Her ne kadar 2821 sayılı Sendikalar Kanunu, 6356 sayılı Kanun ile yürürlükten kaldırılmışsa da; 6356 sayılı Sendikalar ve Toplu İş Sözleşmesi Kanunu'nun 81/2 hükmüne göre " Diğer mevzuatta 2821 ve 2822 sayılı kanunlara yapılan atıflar bu Kanuna yapılmış sayılır". Bu düzenleme çerçevesinde, 4688 sayılı Kanun'un 2821 sayılı Sendikalar Kanununa yaptığı atfın 6356 sayılı Kanun'a yapılmış sayılır ve dolayısıyla işyerlerinin girdiği hizmet kolu ve hizmet kolu istatistiklerine itiraz konularında 6356 sayılı Kanun'un ilgili hükümlerinin uygulama alanı bulur (Esener ve Gümrükçüoğlu, 2014; Sur, 2015; Tuncay ve Savaş 2013;). Aynı doğrultuda Yargıtay'da vermiş olduğu kararında hizmet kolu istatistiğine itiraz davalarının kamu düzenine ilişkin olduğunu, bu durumda o hizmet kolundaki tüm sendikaların hasım gösterilerek dava açılması gerektiğine karar vermiştir (Y.9.H.D, 2006).

\section{Kuruluş Şartları ve Usulü}

\section{Kurucularda Aranan Sartlar}

Kamu Görevlileri Sendikaları ve Toplu Sözleşme Kanunu'na göre sendika kurucusu olabilmek için kamu görevlisi olarak çalışmak yeterli olup; en az yedi kamu görevlisinin bulunması gerekmektedir. Her ne kadar 4688 sayılı Kanun ilk halinde sendika kurucusu olabilmek için en az iki yıldan beri kamu görevlisi şartını aramışsa da 2012 yılında kabul edilen metinle birlikte söz konusu iki yıl şartı Kanundan çıkarılmıştır. Bu şarta yasada yer verilmesinin nedeni en çok iki yıl süren adaylık süreci olsa da düzenlemenin sendika hakkının ayrım gözetilmeksizin tüm çalışanlara tanınması yönündeki 87 sayılı Sözleşmenin 2. maddesine aykırı olmasıdır. Bu anlamda maddenin örgütlenme özgürlügüunü kısıtlayıcı niteliği ortadır. Kaldı işçi sendikası kurucusu olabilme anlamında kıdem koşulu aranmazken; kamu görevlilerinde böylesi bir şartın aranması eşitsizliğe yol açması bir yana; hakkaniyete aykırı sonuçlara neden olur. Dolayısıyla 6289 sayılı Kanunla birlikte iki yıllık süre şartının kaldırılması Sözleşmeye uyumun sağlanması ve işçi, kamu görevlisi arasındaki örgütlenme özgürlüğü esaslı eşitsizliklerin giderilmesi bakımından olumlu bir gelişmedir.

İşçi sendikası kuruculuğu için bir dizi şartlar aranırken kamu görevlileri sendikası kuruculuğu için sadece kamu görevlisi olma şartının aranması dikkat çekici olmakla birlikte; 6356 sayılı Kanunun 6. maddesinde sayılanlar gibi bir hüküm 4688 sayılı Kanun'da yer almadığından, bu Kanunda hüküm bulunmayan hallerde uygulanacak kanunları gösteren 43. madde uyarınca 6356 sayılı Kanunun 6. maddesinde gösterilen şartların kamu görevlileri sendikaları açısından da arandığının kabulü yerinde olacaktır. Bu çerçevede kamu görevlileri sendikalarında kurucu olmak için yalnızca kamu görevlisi olarak çalışmak yeterli olmayıp:

- Fiil ehliyetine sahip olma,

- Fiilen çalışma,

- Türk Ceza Kanununun 53. maddesinde belirtilen süreler geçmiş olsa bile; zimmet, irtikap, rüşvet, hırsızlık, dolandırıcılık, sahtecilik, güveni kötüye kullanma, hileli iflas, ihaleye fesat karıştırma, edimin ifasına fesat karıştırma, suçtan kaynaklanan mal varlığı değerlerini aklama ve kaçakçılık suçlarından birinden mahkum olmama koşullarına sahip olma zorunluluğu bulunmaktadır. 


\section{Kuruluș Șartları}

Daha önce de arz ettiğimiz üzere kamu görevlileri sendikalarının kuruluşunda serbest kuruluş esası benimsenmiş olup; kuruluş için önceden izin alınması gerekmez. Bu durum kamu görevlileri sendikalarının hiçbir yasal prosedür gerekmeksizin kurulabildiği şeklinde yorumlanmamalıdır. Kamu görevlileri sendikalarının kuruluşu için sendikanın kurucularının kuruluş dilekçesi ile birlikte, sendika tüzüğünü, kamu görevlisi olduklarına dair belgeleri ve sendikayı ilk genel kurula kadar idare edeceklerin isimlerini sendika merkezinin bulunacağ ilin valiliğine teslim etmeleri gerekmektedir (Esener ve Gümrükçü, 2014).

4688 sayılı Kanun'un 7. maddesi uyarınca:

a) Sendika ad1, merkezi, adresi,

b) Sendikanın amacı, çalışma konuları ve usulleri,

c) Sendikanın faaliyet göstereceği hizmet kolu,

d) Sendika kurucularının kimlik bilgileri, meslek veya görevleri, adresleri,

e) Üyelik koşulları, üyelik ödentisinin oranı, üyelikten çıkma ve çıkarılmanın usul ve esaslar1,

f) Genel kurul delegelerinin belirlenme usulü,

g) Genel kurulun görev ve yetkileri, oy kullanma ve karar alma usul ve yeter sayıları ile yönetim, denetleme ve disiplin kurullarının oluşumu, görevleri ve toplantı usulleri ile iç denetim usulü,

h) Genel kurul dışındaki zorunlu organlarına üye seçilme usulü, asil ve yedek üye sayıs1, görev ve yetkileri,

i) Yöneticilerde aranacak şartlar,

j) Şubelerin kuruluş esasları, görev ve yetkileri,

k) Harcama yetki, yöntem ve esasları, gelirlerin ne şekilde muhafaza edileceği ve kasada tutulacak azami nakit mevcudu ile demirbaşların satış ve terkininde uygulanacak usul ve esaslar,

1) Tüzüğün değiştirilme ve ayrıca mal varlığının tasfiye usulü,

m) Zorunlu organların oluşumuna kadar görev yapacak geçici yönetim kurulu üyelerinin kimlik bilgileri ve adresleri,

n) Sendika temsilcilerinin seçiminde yetkili kurulun belirlenmesi, temsilcilerin nitelikleri ve görevden alınma usullerine tüzükte yer verilmesi zorunludur.

Belirtilen belge ve tüzüğün valiliğe verilmesi ile sendika tüzel kişilik kazanır. Valilik, tüzük ve belgelerin birer örneğini, on beş işgünü içinde bilgi kaydı tutulmak üzere Çalışma ve Sosyal Güvenlik Bakanlığına gönderir. Her ne kadar valiliğin evrakları kabul etmeyerek iade yetkisi bulunmamaktaysa da ${ }^{\mathrm{i}}$ kuruluş belgelerinde kanuna aykırılık yahut kuruluş şartlarında

\footnotetext{
${ }^{\text {i }}$ Her ne kadar sendikal örgütlerin kuruluşu için serbest kuruluş sistemi benimsenmişse de uygulamada bu sistemin zedelendiğini hatta adeta bir izin sisteminin uygulandığını söylemek mümkündür. Nitekim 9 Kasım 2012 tarihinde, emniyet hizmetlerinde ve teşkilatında çalışanların kurmuş olduğu Tüm Çalışan Emniyet Hizmetleri Sınıfı ve Emniyet Teşkilatında Çalışan Diğer Tüm Hizmet Sınıflarına Dahil Personel Sendikasının başvuru evrakları emniyet teşkilatında örgütlenme hakkı olmadığı gerekçesiyle Ankara Valiliği tarafından iade edilmiş; sendika söz konusu belgelerin kargo ile valiliğe gönderilmesi sonrasında tüzel kişilik kazanabilmiştir. Benzer durum bir hafta sonrasında 16 Kasım 2012 tarihinde Yargıçlar Sendikasında da yaşanmış başvuru belgeleri Ankara Valiliği
} 
eksiklik tespit edilmesi mümkündür. Böylesi bir durumla karșılașılması halinde valilik tarafından eksikliklerin giderilmesi için bir ay süre verilir. Bu süre içerisinde eksiklik tamamlanmadığ başvuruda bulunur. İş mahkemesi sendikaya kanuna aykırılığın yahut eksikliğin giderilmesi için altmış güne kadar süre verir. Süre sonunda gerekli düzenlemeleri yapmayan sendika hakkında mahkemece kapatma kararı verilir.

Doktrinde mahkeme tarafindan kapatma yerine faaliyetin durdurulması kararı da verilebileceği ileri sürülmüş olsa da (Gerek, 2003).; kanaatimizce faaliyeti durdurulmuş bir sendika için ayrıca tekrar böylesi bir karar alınmasının yersizliği bir yana; mahkeme tarafından tanınan süreye uyulmamış bir sendika için faaliyetin durdurulması yeterli bir yaptırım sonucu sağlamaktan da uzak kalacaktır. Kaldı ki böyle bir sonucun kabulü faaliyetin durdurulmasını önlem, kapatmayı ise yaptırım olarak nitelendiren hükmün emredici niteliği ile de bağdaşmayacaktır.

\section{Üyelik Hakkı}

İşçi ve işverenler için tanınmış olan sendika hakkı kamu görevlilerini kapsayacak şekilde Anayasa ile güvence altına alınmıştır. Anayasanın 51. maddesine göre çalışanlar kapsamında yer almakla kamu görevlileri de "üyelerinin çalışma ilişkilerinde, ekonomi ve sosyal hak ve menfaatlerini korumak ve geliştirmek için önceden izin almaksızın sendikalar ve üst kuruluşlar kurma, bunlara serbestçe üye olma ve üyelikten çekilme hakkına sahiptir. Hiç kimse bir sendikaya üye olmaya ya da üyelikten ayrılmaya zorlanamaz" ve buna uygun olarak "kamu görevlilerinin bu alandaki haklarının kapsamı, istisna ve sınırları gördükleri hizmetin niteliğine uygun olarak kanunla düzenlenir." Sendikaya üyelik hakkı, uluslararası belgelerde ve sözleşmelerde temel haklar kategorisinde yer almıştır. Ülkemizde de üyelik hakkı anayasal düzeyde kabul görmüștür. Buna uygun olarak 4688 sayılı Kanunda gerekli prosedürleri yerine getiren kamu görevlilerinin özgürce sendikaya üye olabilmeleri kabul edilmiş ve bu hakkın serbestçe kullanılmasına ilişkin koruyucu düzenlemelere yer verilmiştir.

4688 sayılı Kanun'un 3. maddesi uyarınca, bu Kanun kapsamında yer alan kurum ve kuruluşları kadro veya pozisyonlarında istihdam edilmekte olanlardan işçi statüsü dışında çalışan kamu görevlileri, sendika üyesi olabilecektir. Söz konusu hükmün özgürlükçü yaklaşımı karşısında tüm kamu görevlilerinin sendika üyesi olabileceği sonucuna varılmamalıdır. Zira aynı Kanun'un 15. maddesinde sendika üyesi ve kurucusu olamayacaklar arasında sayılmamış olmak şartıyla kamu görevlilerinin sendika üyesi olabilecekleri hüküm altına alınmıştır.

\section{Üye Olmalarına İzin Verilmeyenler}

Özgürlükçü bir yorumla kamu görevlisinin geniş bir tanıma tabi tutulması ve bu suretle sendikal özgürlüklerin kapsamının bireysel olarak genişletilmesi son derece önemlidir. Ancak yine de Yasanın ilgili hükmünün özgürlükçü bir yapıya sahip olmadığını ifade etmenin gerçekçi olacağı kanaatindeyiz. 4688 sayılı Kanun'un 15. maddesinde oldukça geniş bir dizge içerisinde kamu görevlisi olmakla birlikte üyeliğe yönelik yasaklamalara yer verilmesi dikkat çekicidir. 15. madde hükmüne göre bu Kanuna göre kurulan sendikalara;

a) Cumhurbaşkanlığı Genel Sekreterliği ile Millî Güvenlik Kurulu Genel Sekreterliğinde çalışan kamu görevlileri,

b) Yüksek yargı organlarının başkan ve üyeleri, hâkimler, savcılar ve bu meslekten sayılanlar, 
c) Bu Kanun kapsamında bulunan kurum ve kuruluşların müsteşarları, başkanları, genel müdürleri, daire başkanları ve bunların yardımcıları, yönetim kurulu üyeleri, merkez teşkilâtlarının denetim birimleri yöneticileri ve kurul başkanları, hukuk müşavirleri, bölge, il ve ilçe teşkilâtlarının en üst amirleri ile bunlara eşit veya daha üst düzeyde olan kamu görevlileri, belediye başkanları ve yardımcıları,

d) Yükseköğretim Kurulu Başkan ve üyeleri ile Yükseköğretim Denetleme Kurulu Başkan ve üyeleri, üniversite ve yüksek teknoloji enstitüsü rektörleri, fakülte dekanları, enstitü ve yüksek okulların müdürleri ile bunların yardımcıları,

e) Mülkî idare amirleri,

f) Silahlı Kuvvetler mensupları,

g) Millî İstihbarat Teşkilâtı mensupları,

h) Bu Kanun kapsamında bulunan kurum ve kuruluşların merkezi denetim elemanları,

i) Emniyet hizmetleri sinifi

j) Ceza infaz kurumlarında çalışan kamu görevlileri, üye olamazlar ve sendika kuramazlar.

Söz konusu hükümdeki "Türkiye Büyük Millet Meclisi Başkanlığı İdari Teşkilatı" ibaresinin Anayasa Mahkemesi tarafından iptal edilmiş olması son derece ilgi çekicidir (AYM, 2015). Anayasa Mahkemesi söz konusu kararında, AİHM'nin Demir/Baykara kararına yollama yaparak, TBMM Başkanlığı idari personelinin, sendikal haklardan yoksun bırakılmasını gerektirir telafisi güç, imkansız zararlar doğuracak, ikna edici ve zorlayıcı gerekçeleri bulunmadığına hükmetmiştir. Söz konusu karar UÇÖ sözleşmelerinde yer alan fiilen otoriteyi kullanan üst düzey yöneticiler ve istihbarat teșkilatları dışındaki personelin istisna edilemeyeceği yönündeki düzenlemelerine de uygundur. Bu kapsamda başvuru halinde, Cumhurbaşkanlığı Genel Sekreterliği ile Millî Güvenlik Kurulu Genel Sekreterliğinde çalışan üst düzey yöneticiler dişındaki personele yasak getiren madde hükmünün de UÇÖ sözleşmelerine aykırı olduğu kanaatindeyiz.

Anayasa Mahkemesi'nin kararına rağmen mevcut haliyle söz konusu madde halihazırda açık bir biçimde örgütlenme özgürlüğünü ihlal eder niteliktedir (Nizamettin, 1998). Sendika kurma hakkı kuşkusuz mutlak bir hak olmayıp Anayasa'nın 51. maddesinin ikinci fikrası uyarınca millî güvenlik, kamu düzeni, suç işlenmesinin önlenmesi, genel sağlık ve genel ahlâk ile başkalarının hak ve özgürlüklerinin korunması sebeplerine dayanılarak kanunla sınırlanması mümkündür. Öte yandan anılan maddenin beşinci fikrasında, "İşçi niteliği taşımayan kamu görevlilerinin bu alandaki haklarının kapsam, istisna ve sınırları gördükleri hizmetin niteliğine uygun olarak kanunla düzenlenir." hükmüne yer verilerek, ikinci fikradaki genel sinırlama sebepleri dışında da bazı kamu görevlileri yönünden bu hakkın kapsamının daraltılması veya sınırlandırılması ya da hakkın kullanımının yasaklanması da mümkün kılınmıştır. Kanun koyucu Anayasanın tanımış olduğu kısıtlama yetkisini sendikal özgürlükler aleyhine kullanmış ve bu çerçevede üyelik yasaklarını geniş bir perspektife oturtmuştur. Bununla birlikte kanun koyucunun hakkın kapsamına negatif yönde müdahale ederken özgürlükçü bir yaklaşım sergilemesi, sendikaların çoğulcu demokrasinin vazgeçilmez unsurları olması ile paraleldir. $\mathrm{Bu}$ bakımdan üyelik yasağı anlamında düzenleme yapılması suretiyle kamu görevlilerinin sendikal haklarına ilişkin olarak getirilen kısıtlamaların, gördükleri hizmetin nitelikleriyle uyumlu olması gerekmektedir. Oysa ki yasada bu türlü bir kısıtlama gerekçesi aranmaksızın geniş haliyle bir sınırlama sistemi kurgulanmış mesleki ve idari hiyerarşideki konuma göre üyelik yasakları düzenlenmesine gidilmiştir.

Nitekim ilgili kanun hükmünde yer alan "Millî Savunma Bakanlı̆̆ ile Türk Silahlı Kuvvetleri kadrolarında (Jandarma Genel Komutanlı̆̆ ve Sahil Güvenlik Komutanlı̆̆ dahil) çallşan sivil memurlar ve kamu görevlilerine" yönelik düzenleme de bu doğrultuda Anayasa Mahkemesi tarafından iptal edilmiştir. Anayasa Mahkemesi iptal kararında, Anayasa'nın 51. 
maddesinin beșinci fikrasında belirtilen sebeplerle sendika kurma ve sendikalara üye olma hakkına yönelik müdahalelerin, Anayasa'nın 13. maddesi uyarınca, demokratik toplum düzeninin gereklerine ve ölçülülük ilkesine aykırı olamayacağını ortaya koymuş; Anayasa'nın 51. maddesinin birinci fikrasında, sendika kurma ve sendikalara üye olma hakkı tüm çalışanlar yönünden güvence altına alındığından Millı̂ Savunma Bakanlığı ve Türk Silahlı Kuvvetleri kadrolarında çalışan sivil memurlar ve kamu görevlilerinin sendika kurması ve sendikalara üye olmasını yasaklayan dava konusu kuralın, sendika kurma hakkına müdahale niteliği taşıdığ1 sonucuna varmıştır (AYM, 2013).

Sendika hakk1, demokratik toplumun temeli olan örgütlenme özgürlüğünün bir parçasıdır. Örgütlenme özgürlüğü, bireylerin kendi menfaatlerini korumak için kolektif oluşumlar meydana getirerek bir araya gelebilme özgürlügüüür. Bu özgürlük, bireylere bir araya gelerek topluluk halinde siyasal, kültürel, sosyal ve ekonomik amaçlarını gerçekleştirmelerine imkân sağlar. Bir ülkenin demokratik hayatında işçilerin elde ettiği haklar arasında sendikalaşmanın birincil öneme haiz olduğu bir gerçektir. Sendikalaşmanın ve sendikacılığın kendine özgü bazı ihtiyaçları vardır ve bu gereklerin başında da en geniş ölçüsüyle dayanışmanın sağlanması gelmektedir (Yılmazer, Dallı ve Arpad, 1962). Bunun sonucu olarak ta sendika hakkı, çalışanların bireysel ve ortak çıkarlarını korumak amacıyla bir araya gelerek örgütlenebilme serbestisini gerektirmekte olup, bu niteliğiyle örgütlenme özgürlüğünün bir parçası olarak görülmektedir. Kamu çalışanlarının örgütlenebilmeleri, kabul gören geri adım atılamayacak bir hale geldiği mevcut durumda, üyeliğin bu denli aşırı bir biçimde kısıtlanması hukuki yönden kamu görevlilerinin iş koşulları ve özlük hakları konusunda devletin tek taraflı düzenleme yetkisinden vazgeçmek istemediği sonucunu doğurmaktadır. Aksi bir düşünce devletin hizmetkarları sayılan ve devlet otoritesini temsil etmekte olan kamu görevlilerinin devlete karşı zıt çıkarları olamayacağından hareketle sendika hakkı tanınmasının gereksiz olduğu yönündeki düşüncenin örgütlenme özgürlüğünün önüne geçmesini beraberinde getirecektir (Tuncay, 1974).

Karşılaştırmalı hukuk sistemlerindeki yaklaşım ise Türk Hukukundan oldukça önemli farklılıklar içermektedir. Almanya'da devlet düzeninin işlerliğini ağır ölçüde tehlikeye sokmayacak işler kavramı getirilerek bu sınırın içinde kalan kamu çalışanlarına sendika hakkı tanınmamıştır. Belçika'da ise kamu çalışanlarının tamamına sendika hakkı tanınmıştır. İsveç'te de kamu çalışanlarının tamamını içerecek şekilde sendika hakkı tanınmıştır. Aynı doğrultuda İngiltere, İtalya ve Fransa'da da kamu kesimi dahil sendikalaşma hakkı çalışanların bütünü için kabul edilmiş bulunmaktadır (Aktay, 1993).

Doktrinde kapsam dıșı bırakılacak kamu görevlilerinin daha da dar bir yapı içerisine alınması ve ILO sözleşmelerine uygun olarak, yalnızca devlet yönetiminin üyeleri yani yönetimin sert çekirdeğinde görevli olan kamu görevlileri ile sınırlanması, bunun dışında kalan kamu görevlilerine sendikal hakların tanınmaması gerektiği görüşünün doğru olduğu kanaatindeyiz (Gülmez 2014).

Zira önceden de belirttiğimiz üzere, konuya ilişkin 87 Sayılı Sendika Özgürlüğü ve Sendika Hakkının Korunması Sözleşmesi'nin kişi yönünden uygulama alanını düzenleyen 2. maddesi "Çalışanlar ve işverenler herhangi bir ayrım yapılmaksızın önceden izin almadan istedikleri kuruluşları kurmak ve... bunlara üye olmak hakkına sahiptir" hükmü ile sendikal örgütlenme hakkını işçi, memur, sözleşmeli personel gibi ulusal mevzuatlarda değişik biçimlerde tanımlanan bağımlı çalışanların bir kesimine değil hepsine tanımıştır (Tosun, 2011). Kaldı ki 87 sayılı ILO Sözleşmesi sendikal örgütlenme hakkını işçi ve işverenler yanında kamu görevlilerine de tanıdıktan sonra Sözleşmede öngörülen güvencelerin silahlı kuvvetlere ve polis memurlarına ne ölçüde uygulanacağının belirlenmesi işini(onları bu haktan tamamen yoksun bırakmadan) ulusal mevzuata bırakarak, son derece özgürlükçü bir anlayış tanımlamıştır. Aynı 
doğrultuda Kamu Hizmetinde Örgütlenme Hakkının Korunması ve Çalışma Şartlarının Belirlenmesi amacıyla çıkarılan 151 sayılı Sözleşme de sendikal güvenceler anlamında devletin üst düzey yöneticileri, gizli görevler ifa edenler, silahlı kuvvetler ve polisler açısından sınırlayıcı nitelikte düzenlemelerin hüküm altına alınmasına imkan tanımıştır. Ancak daha önceden de değindiğimiz üzere gerek ILO denetim organlarının kararlarında gerekse AİHM'nin kararlarında bu sınırlandırmanın söz konusu personeli tamamıyla sendika hakkından yoksun bırakmak şeklinde yorumlanması mümkün değildir. Diğer bir ifade ile 4688 sayılı Kanunda sadece devlet adına kamu gücünü kullanan üst düzey kamu görevlileri, MİT mensupları, güvenlikle ilgili emniyet mensupları ile silahlı kuvvetler mensubu kamu görevlilerinin sendikal hakları kisitlanabilir ama tamamiyla sendikaya üye olmasının yasaklanması hem ILO sözleşmelerine hem de AHİS'sine aykırılık oluşturmaktadır (Tuncay 1974). Bu çerçevede yeni bir yasal düzenleme ile söz konusu hizmet kadrolarında çalışanlara diğerlerinden ayrı olarak kendi sendikalarını kurmalarına ve üye olmalarına imkan sağlanması Türk Mevzuatının uluslararası normlara uygun hale getirilmesi anlamında en kesin çözüm olacağı görüşü ileri sürülmüştür( Kutal, 2007).

4688 sayılı Kanun'un sendika üyesi olamayacakların kategorilerine ilişkin mevcut düzenlemesi, 87 ve 151 sayılı Sözleşmelerde cevaz verilen sınırı ihlal etmiş durumda olup (Kutal, 2006); meşru sınırlamalar olarak ifade edilebilecek olan özgürlüklerin tabi olduğu rejimin özgül kayıtlamalara mahrum edilmemesi yönündeki çağdaş hukuk ilkesi (Kaboğlu, 2001) ihlal edilmiş bulunmaktadır.

\section{Üyeliğin Kazanılması ve Serbesti Esası}

Bireysel sendika özgürlüğü Anayasada düzenlenmiştir. Buna göre çalışanların ve işverenlerin, üyelerinin çalışma ilişkilerinde ekonomik ve sosyal hak ve menfaatlerini korumak ve geliştirmek için önceden izin almaksızın sendika ve üst kuruluşlar kurmaları, bunlara serbestçe üye olmaları ve üyelikten çekilmeleri Anayasa ile güvence altına alınmıştır. $\mathrm{Bu}$ kapsamda yalnızca sendika kurma ve üye olma anlamında olumlu sendika özgürlügü düzenlenmemiş hiç kimsenin bir sendikaya üye olmaya veya ayrılmaya zorlanamaması anlamında olumsuz sendika özgürlüğü de korunmuştur.

4688 sayılı Kanun kapsamında da sendikaya üyelik serbest kılınmıştır. Kamu görevlileri sendikaları açısından hizmet kolu esası benimsenmiştir. Her ne kadar işkoluna göre sendikalaşma ilkesi gereği her bir işkolunun bağımsız olarak ele alınması mantıki bir yol olarak görünse de (Günay, 2008); işyeri bazında örgütlenme esasının işveren karşısında pazarlık gücüne olumlu etkileri olabileceği göz ardı edilmemelidir. Yine de işyeri esaslı örgütlenmenin, muhatabın idari vasfı ve süreci yönlendirmesi anlamındaki orantısız gücü dikkate alındığında, kamu görevlileri sendikacılığı bakımından fayda sağlamayacağı aşikardır. Dolayısıyla, mevcut yönetim teşkilatlanması karşısında, hizmet koluna dayalı örgütlenmenin kamu görevlilerinin vasfina, üstlendikleri göreve ve muhatap konumundaki idare ile olan pazarlık sürecine daha uygun sonuçlar sağlayacağ 1 kuşkusuzdur.

Hizmet kolu esasına uygun olarak, kamu görevlileri sadece çalıştıkları işyerinin girdiği hizmet kolunda kurulu bir sendikaya üye olabilirler.(Esener ve Gümrükçü, 2014) Buna uygun olarak devlet üniversitesi gibi bir kamu kurumunda sekreter olarak çalışan bir görevli yaptığ iş niteliği itibariyle büro işi olsa da, büro hizmet kolundaki bir sendikaya değil, yalnızca eğitim, öğretim ve bilim hizmet kolunda bir sendikaya üye olabilmektedir.( Uçkan, 2013) Kamu görevlilerinin aynı anda birden çok sendikaya üye olması ise sendika üyeliğinde teklik ilkesinin benimsenmesinin sonucu olarak Yasayla yasaklanmıştır.(Esener ve Gümrükçü 2014) Bu yasağa aykırı davranılması halinde ise tüm üyelikler değil yalnızca sonraki üyelikler geçersiz sayılmaktadır. Aynı tarihli birden fazla üyeliğe ilişkin bildirimler ise dikkate alınmaz. Bu husus, kamu işvereni tarafından ilgiliye ve sendikalara yazılı olarak bildirilmek zorundadır. 
Sendikaya üye olmaya ilișkin hükümler ise sendika özgürlüğüne katk1 sağlayacak şekilde düzenlenmiştir. Bunun sonucu olarak gerek üye olma ve gerek üyelikten çekilmede noter aracılığı aranmamaktadır. Kamu görevlileri sendikaya üye olmak için çalıştıkları işyerinin girdiği hizmet kolunda kurulu sendikaların birinden temin edeceği üye formunu üç nüsha olarak doldurup imzalayacak ve üye olmak istediği sendikaya başvuracaktır.

Kamu görevlisinin başvurusunun sendika yetkili organınca kabulü ile sendika üyeliği kazanılmış olur. Ancak sendika üyeliğine kabul serbestisini sınırlamak ve bu alandaki keyfi işlemlere engel olmak üzere Yasanın 14/4 maddesi ile üyelik başvurusunun sendika tarafından en çok otuz günlük süre içerisinde reddedilmemesi halinde üyelik isteminin kabul edilmiş sayılacağı kabul edilmiştir (Aktay, Arıcı ve Kaplan, 2009).

Sendika haklı bir sebep göstermek suretiyle üyelik başvurusunu reddedebilir. Kamu görevlisinin aynı anda birden fazla sendikaya üye olmak istemesi yahut çalıștığı işyerinin kurulu bulunduğu hizmet kolu dışında faaliyet gösteren bir sendikaya üyelik başvurusu yapması üyelik isteğinin reddi için haklı sebep olarak ileri sürülebilir. Ancak ırk, din, dil, mezhep, siyasi düşünce farklılığı gibi negatif ayrımcılığ (Sümer, 2015). Haklı bir sebep gösterilmeden üyeliği kabul edilmeyen kamu görevlisi, bu kararın kendisine tebliğinden itibaren otuz gün içinde dava açabilir. Her ne kadar davacı kamu görevlisi olsa da bu durum görevli mahkeme açısından etki doğurmaz ve başvuru İş Mahkemesine yapılır (Sur, 2015). Böylece kamu görevlilerinin sendikaca hakkın kötüye kullanılması niteliğindeki işlemlere maruz bırakılmasına karşı üye kabul serbestisi koruma altına alınmıştır(Aktay, Arıcı ve Senyen Kaplan, 2009).

Sendikaya üyeliği ister sendikanın açık yahut zımni kabulü ile isterse mahkeme kararı ile olsun, üyeliğin kesinleşmesi sonrasında üyelik başvuru belgelerinin bir örneği kamu görevlisine verilir. Bir nüsha sendikada kalır, diğer bir nüsha ise üyelik ödentisine esas olmak ve dosyada saklanmak üzere 15 günlük süre içinde üye kamu görevlisinin işverenine gönderilir. Kamu Görevlileri Sendikaları ve Konfederasyonlarınca Düzenlenecek Üyeliğe Başvuru Belgesi, Çekilme Bildirimlerinin Şekli, İçeriği, Tutulacak Defterlerin Şekli, İhtiva Edeceği Bilgiler ile Kayıtların Düzenlenmesine İlişkin Usul ve Esaslar Hakkında Yönetmeliğe göre, kamu işvereni sendikaya üye olan ve üyelik ödentisi kesilen kamu görevlilerinin listesini her ayın son haftasında herkesin görebileceği bir yerde ilan etmek zorundadır.

\section{Üyelerin Hak ve Yükümlülükleri}

\section{Üyelikten doğan haklar}

4688 sayılı Kanunun 19/2 hükmü uyarınca toplumsal cinsiyet eşitliğinin gözetilmesi ve ayrımcılık yapılmaması ilkeleri saklı kalmak üzere, üyelerin sendika ve konfederasyonların taraf olduğu toplu iş sözleşmesinden yararlanma, yönetime ve faaliyetlere katılma, tesis ve faaliyetlerden yararlanma hakları bulunmaktadır.(Esener ve Gümrükçü, 2014) Üyelik, üye açısından kişiye doğrudan bağlı bir hak olduğu için hak ve yükümlülükleri devredilemediği gibi miras yoluyla da aktarılamaz (Uçkan, 2013). 4688 sayılı Kanun uyarınca kamı görevlileri sendikalarının üyeleri:

- Sendika tarafından düzenlenen mesleki yeterliliklerinin artırılması ve sorunlarının çözülmesi ile sendikal faaliyetlerinin geliştirilmesine yönelik kurs, seminer ve sosyal amaçlı toplantı ve bilimsel çalışmalara katılmak,

- Kendileri ve ailelerinin yararlanmalarına yönelik, eğitim ve sağlık tesisleri, dinlenme yerleri, spor alanları ve benzeri yerler ile kitaplık, kreş, yuva ve huzur evleri, yardımlaşma sandıkları ve kooperatiflerinden yararlanmak,

- Sendika içi demokrasi ilkesi çerçevesinde genel kurula katılmak, oy kullanmak, delege olmak, genel kurul dişındaki organlarda görev almak için aday olmak ve seçilmek; 
ayrıca olağanüstü genel kurul toplamak, eleştiri, şikayet ve sendika kararlarına karşı mahkemeye başvurmak,

- Diledikleri zaman sendikadan ayrılmak haklarına sahiptirler.

\section{Üyelikten doğan borçlar}

Sendika üyeliğinden doğan borçlar aidat ödeme borcu ile sendika düzenine ve amaçlarına uygun davranma olarak ikiye ayrılabilir.

\section{Üyelik ödentisi(aidat) ödeme}

Üyelik borçları arasında en somut olanı, aidat ödeme yükümlülüğüdür (Sur, 2015). Sendika için en önemli gelir kaynağı olan aidat ödeme borcu Yasanın 25. maddesinde üyelik ödentisi adı ile ifade edilmiştir. Üyelik ödentisinin oranı, sendika tüzüğünde belirlenmek zorunda olup, sendika tüzüğüne üyelik ödentisi dışında her ne ad altında olursa olsun üyelerde başkaca bir kesinti yapılmasına dair hüküm konulamaz. Aylık üyelik ödenti tutarı ise kamu görevlisinin kadro ya da pozisyonuna bağlı ve her ay mutat olarak ödenmekte olan damga vergisine tabi aylık brüt gelirleri toplamına, sendika tüzügünde belirtilen oran uygulanarak hesaplanacaktır. Ancak bu durum ödenti tutarının sınırsız olarak belirlenebileceği anlamına gelmemelidir. Yasa ödenti tutarına ilişkin olarak 15. derecenin birinci kademesinden aylık alan devlet memurunun damga vergisine tabi brüt gelirleri toplamının binde dördünden az, otuzda birinden fazla olmamak yönünde kesin bir sınırlayıcı hüküm getirmiştir.

Kamu görevlileri sendikalarına yönelik üyelik aidatı işçi sendikalarına nazaran daha düşük miktarlarda ise de asıl ilgi çekici olan sendika üyeliğini özendirmek ve sendika üyesi olanla olmayan arasındaki farkı belirlemek maksadıyla ihdas edilen sendika ödeneği hususudur. 31.03.2006 tarihli ve 26125 sayılı Resmi Gazete'de yayınlanarak yürürlüğe giren 5473 sayılı Değişik Adlar Altında İlave Ödemesi Bulunmayan Memurlara ve Sözleşmeli Personele Ek Ödeme Yapılması ile Bazı Kanun ve Kanun Hükmünde Kararnamelerde Değişiklik Yapılması Hakkında Kanun ile 375 sayılı Kanun Hükmünde Kararnameye yapılan ekleme ile "kamu görevlileri sendikasına üye olup, kendisinden üyelik ödentisi kesilen kamu görevlilerine, anılan kesintinin yapıldığı her ay için 5 TL tutarında sendika ödeneği verileceği ve bu ödemenin damga vergisi hariç herhangi bir vergi yahut kesintiye tabi tutulamayacağ 1 ve ilgili mevzuat uyarınca ödenmekte olan zam, tazminat, ödenek, döner sermaye payı, ikramiye, ücret ve her ne ad altında olursa olsun benzeri ödemelerin hesabında dikkate alınamayacağı hükme bağlanmıştır. Bu miktar sendikaya ödenen ücret olarak değil; sadece üyelere devlet tarafından ödenen bir meblağ olarak tanımlanmıştır. Sendika ödeneğinin miktarı 2009 Bütçe Kanunu ile 10 TL'ye çıkarılmış ve ismi toplu görüşme primi olmuştur.

Anayasa Mahkemesi, 5473 sayılı Kanunla yapılan düzenlemeyi, demokratik ilkelere aykırı olması, kamu işvereninin sendikalara müdahalesinin önünü açması çerçevesinde Uluslararası Çalışma Örgütü'nün Teşkilatlanma ve Kolektif Müzakere hakkı Prensiplerinin Uygulanmasına Müteallik 98sayılı ve Kamu Hizmetinde Örgütlenme Hakkının Korunması ve İstihdam Koşullarının Belirlenmesi Yöntemlerine İlişkin 151 sayılı sözleşmelerine ve dolayısıyla Anayasanın 90. maddesine aykırı görerek iptal etmiştir ( AYM, 2009). Anayasa Mahkemesi'ne göre bu türlü bir düzenleme kamu işvereninin mali yolla sendikalara müdahalesinin önünü açarak sendikal bağımsızlık ilkesini zedelemiştir. Ayrıca ücret durumuna göre sendikaya üye olan yüksek ücretli kamu görevlilerinde kayba, düşük ücretli kamu görevlilerinde ise kazanca yol açarak, işçi ve kamu görevlileri arasında neden olduğu ayrımcılık bir yana,hukuksal durumları aynı olan sendika üyeleri arasında avantaj ve dezavantajları beraberinde getirmesiyle kanun önünde eşitlik kuralını da ihlal etmiştir. 
Anayasa Mahkemesi'nin iptal kararında belirttiği gerekçelere rağmen 13.2.2011 tarihli 6111 sayılı Kanun'un 118. maddesi ile 375 sayılı Kanun Hükmünde Kararnameye iptal edilen ek 4. madde hükmüne karşılık gelmek üzere; kamu görevlileri sendikalarına üye olup, aylık veya ücretinden üyelik ödentisi kesilen kamu görevlilerine ocak, nisan, temmuz ve ekim aylarında aylık veya ücretleri ile birlikte kırk beş Türk Lirası toplu sözleşme ikramiyesi ödeneceği, bu ödemenin damga vergisi hariç herhangi bir vergi yahut kesintiye tabi tutulamayacağı ve ilgili mevzuat uyarınca ödenmekte olan zam, tazminat, ödenek, döner sermaye payı, ikramiye, ücret ve her ne ad altında olursa olsun benzeri ödemelerin hesabında dikkate alınamayacağı hükmü eklenmiştir. 2012 yılında 4688 sayılı Kanunda yapılan değişiklikle birlikte toplu sözleşme primi, toplu sözleşme ikramiyesi adını almış, miktarının ise toplu sözleșme ile belirleneceği kabul edilmiștir. Söz konusu ikramiyeyi sendika bağımsızlığını zedeleyen bir husus olmaktan çok hak olarak kabul eden Memur-Sen'in taraf olduğu, 14 Ağustos 2013 tarihli Resmi Gazete'de yayımlanan Kamu Görevlilerinin Geneline ve Hizmet Kollarına Yönelik Mali ve Sosyal Haklara İlişkin 2014 ve 2015 Yıllarını Kapsayan 2. Dönem Toplu Sözleşme'nin 26.maddesinde de 375 sayılı Kanun Hükmünde Kararnamenin ek 4 üncü maddesine atıf yapılmış, sadece hükümde sözü geçen "kırk beş Türk Lirası" ibaresi yerine "altmış Türk Lirası"nın uygulanacağı hükme bağlanmıştır. Bu çerçevede 1.1.2015 yılından itibaren de dahil olmak üzere toplu sözleşme ikramiyesi altmış TL olmak üzere uygulanmaya devam etmektedir.

Kanaatimizce, söz konusu düzenlemede her ne kadar yapılan ödemenin tanımında değişikliğe gidilmişse de, Anayasa Mahkemesinin anılan iptal gerekçelerinin söz konusu hüküm açısından da aynı ölçüde geçerli olup; bu haliyle madde, gerek kanun önünde eșitlik ve gerek sendikaların bağımsızlığı ilkeleri anlamında Anayasaya aykırıdır ve iptali gerekmektedir.

6356 sayılı Kanuna paralel olarak 4688 sayılı Kanun'da da "checkoff" sistemi benimsenmiştir. Sendikalar ve Toplu İş Sözleşmesi Kanunu'ndan farklı olarak ise "checkoff" sisteminin uygulanabilmesi sendikanın yetkili olması ve işverene başvuruda bulunması şartına bağlanmamıştır. Kamu görevlisi veya sendikanın talebi aranmaksızın kamu işvereninin üyelik ödentisine ilişkin kesintiyi yaparak sendika hesabına yatırması gerekmektedir (Tuncay ve Savaş, 2013). Dolayısıyla üyelik ödentisinin tahsilini kolaylaştırmak maksatlı olarak benimsenen "checkoff" sistemi uyarınca kamu işvereni üyelik ödentisini kaynakta keserek kamu görevlileri sendikasına ödemekle yükümlüdür. 25/1 hükmü uyarınca üyelik ödentisinin aylıktan kesilerek beş gün içerisinde sendikanın banka hesabına yatırılması ve ödenti listesinin bir örneğinin ilgili sendikaya gönderilmesi gerekir. Üyelik ödentisi kesilen kamu görevlilerinin listesi her ayın son haftasında işveren tarafından işyerinde herkesin görebileceği yerde ve kurumsal düzeyde duyurulabilecek diğer araçlarla ilan edilmesi şarttır.

\section{Sendika Düzenine Uyma Borcu:}

Sendika üyesinin, üyelik ödentisi dışındaki diğer bir yükümlülügü sendika düzenine uyma borcu olup, sendika düzeni başta 4688 sayılı Kanun olmak üzere, sendika tüzüğü, sendika genel kurul kararları ve sendika yönetim kurulunun bu iki düzenleyici kararlara aykırı olmamak üzere alacağı kararlarla belirlenir( Aktay, Arıcı ve Senyen Kaplan, 2009). Üyeler, mevzuatta ve sendikanın tüzügünde yer alan kurallara ve düzene uyarak, sendikanın amaçlarına aykırı ve gelişmesine engel olacak nitelikteki söz ve eylemlerden kaçınmak, yani sendikaların kural koyucu, yönetsel ve mesleki otoritesine uygun davranmak zorundadırlar. Bu bakımdan sendikanın iddialarını yalanlayıcı propaganda yapmak gibi davranışlar sendika düzenine aykırı olacaktır (Sur, 2015). Sendika üyesi kamu görevlilerinin sendika yönetimi tarafından verilen kanuna aykırı olmayan talimatlara da yerine getirmesi de şart olup, sendikanın yapmış olduğu toplu sözleşme hükümlerine uyulması da zorunludur. 
İradi bir ișlemle sendika üyesi olan kamu görevlisi sendika düzenine ilișkin kuralların varlığını bilerek ve kabul ederek üye olmuş kabul edilir. Sendika düzenine aykırı davranan üyelere sendika tüzüğünde belirtilmek ve soruşturma yapmak şartıyla uyarı, kınama, sendikadan çıkarma gibi yaptırımların uygulanması mümkündür (Uçkan 2013).

\section{Üyeliğin Sona Ermesi}

Sendika üyeliği kişiye sıkı sıkıya bağlı haklardan olması itibariyle üyenin ölümü veya gaipliğine karar verilmesi yahut temyiz kudretinin kaybedilmesi hallerinde üyelik kendiliğinden sona erer. Buna paralel olarak sendika tüzel kişiliğinin feshi veya infisahı da aynı hukuki sonucu beraberinde getirecektir. Kamu görevlisinin emekliliği yahut istifası veya hizmet koluna göre örgütlenme esasına uygun olarak farklı bir hizmet koluna tabi işyerinde bir göreve atanması da üyeliğin sona ermesine yol açacaktır. Ancak benzeri hallerden farklı olarak 4688 sayılı Kanunun 16/5 hükmü uyarınca emekli olan sendika üyelerinin, sendika veya konfederasyon organlarındaki görevleri seçildikleri dönemin sonuna kadar devam eder. Ancak bu genel sona erme halleri dışında temel olarak kamu görevlileri sendika üyeliği çekilme ve çıkarılma ile son bulmaktadır.

\section{Çekilme}

Olumsuz sendika özgürlüğünün sonucu olarak kamu görevlileri üyesi oldukları sendikalardan çekilmekte serbesttirler. Serbestiye yönelik düzenleme kamu düzenine ilişkin olup, bu esasa aykırı düzenleme yapılamaz. Yahut sendikadan ayrılma durumunda sendikaya para ödenmesi gibi şartlar kararlaştırılamaz. Kamu görevlisinin üye olarak kalmak istemediği bir sendikaya üye olarak kalmaya zorlanmasının kişilik haklarının ihlali anlamına geleceği gözden uzak tutulmamalıdır. Bu nedenle sendika üyesinin sendika üyeliğinden ayrılmasını olanaksız kılan ya da zorlaştıran sendikanın tüzük hükümleri kişilik haklarının aykırı sayılarak geçersiz kabul edilecektir. Üyelikten çekilme bozucu yenilik doğuran bir hak olup, sendikanın yetkili organının kabulü yahut çalışılan kamu kurumunun onayı aranmayacağı gibi (Sur, 2015); sendika üyesi çekilme hakkını kullanmak için neden bildirmek zorunda da değildir. Sendika tüzüğünde çekilme nedeni bildirme zorunluluğu getirilmesine yönelik düzenlemelere yer verilse dahi, bu türden kurallar olumsuz sendika özgürlügünü kısıtlar nitelik taşıyacağı ve çekilmeye dair emredici hükümlere aykırı olacağından geçersiz kabul edilecektir (Okur, 2013).

4688 sayılı Kanun'un 16/2 hükmü ve 7.9.2001 tarihli Yönetmeliğin 5. maddelerinde çekilmenin usulü ayrıntılı bir şekilde düzenlenmiştir. Üyelikten çekilmek isteyen kamu görevlisi üyelik başvurusuna benzer bir şekilde üç nüsha olarak çekilme bildirimi doldurmak ve imzalamak zorundadır. Söz konusu çekilme bildirimlerinin kamu görevlisince çalıştığ kuruma verilmesi üyeliğin sona ermesi anlamında yeterlidir. Noter aracılığ 1 ile bir başvuru yapılması gerekmediği gibii ${ }^{\mathrm{ii}}$ çekilme bildiriminde bulunan kamu görevlisinin bundan sonraki süreci takip etmesi yönünde bir zorunlulukta söz konusu olmayıp; düzenleme bu hali ile üyelikten ayrılmayı güçleştiren formalitelerin olumsuz sendika özgürlüğünü ihlal ettiği bu nedenle shhhatli olmak kaydı ile çekilme işlemlerinin olabildiğince basit formüle edilmesi yönündeki genel yaklaşıma (Tuncay, 1975) uygundur.

Çekilme bildiriminin bir nüshası kayıt numarası ve tarih işlenerek kendisine iade edilirken bir nüshası da kamu işvereni tarafından 15 gün içinde sendikaya gönderilir. Sendika çekilme bildirimlerinin birer örneğini her yılın Şubat, Mayıs, Ağustos ve Kasım aylarında bir liste ekinde Çalışma ve Sosyal Güvenlik Bakanlığına gönderir.

\footnotetext{
ii İlk kez 1970'te 1317 sayılı Kanunla işçi sendikalarına yönelik olarak getirilen noter şartı sendikadan çıkmayı güçleştiren bir usul olup serbestçe üyelikten ayrılma hakkını zedeler. Ayrıca bu konuda ayrıntılı bilgi için bkz. (Işıklı, 1996). Bu bakımdan çalışanların işten ve gündelikten yoksun bırakan dahası masraf yapmak zorunda bırakan noter usulüne 4688 sayılı Kanunda yer verilmemesi son derece olumlu bir gelişme olarak görülmelidir.
} 
Kamu ișverenleri de, her yılın Mayıs ve Kasım ayı sonu itibariyle kurumlarındaki kamu görevlisi sayısı ile sendika üyesi kamu görevlilerinin sendikalara göre dağılımlarına ilişkin isim listelerini ve sendika üyeliği sona eren veya askıya alınanlara ilişkin bilgileri bilgisayar ortamında Çalışma ve Sosyal Güvenlik Bakanlığı'na ve ilgili sendikaya gönderirler.

Aynı anda birden fazla sendikaya üye olmama yasağı ve buna yönelik hizmet kolu esasına ilişkin düzenlemelere uygun olarak çekilme bildirimi kamu işverenine başvurma tarihinden itibaren 30 gün sonra geçerli olacaktır (Tuncay ve Savaş, 2013). Bu süre içerisinde sendika üyeliğinden doğan tüm hak ve yükümlülükler devam eder ve toplu iş sözleşmesi yetkisinin tespitinde bu kişiler sendika üyesi olarak kabul edilirler. Sendika üyeliğinin sona ermesi için öngörülen otuz günlük süre emredici niteliğe sahiptir. Tüzüğe konulacak hüküm ile bu süre kaldırılamaz, uzatılamaz yahut kısaltılamaz (Sümer, 2015). Bu süre içerisinde başka bir sendikaya üye olunması halinde yeni sendika üyeliği askıda kabul edilir ve ancak bu sürenin bitiminden itibaren geçerlilik kazanır.

\section{Çıkarılma}

Çıkarılma, sendika üyeliğinin sendika yetkili organının kararı ile sona erdirilmesi işlemidir. Sendika üyesinin sendika düzenine uymaması gibi üyelikten doğan yükümlülüklerini ihlal etmesinin yaptırımı olan çıkarma, çıkarılan sendika üyesinin değil, sendikanın iradesi doğrultusunda sona erdirilmesini ifade eder (Aktay, Arıcı ve Senyen Kaplan, 2009). Sendikalar üyelerine uyarı, kınama gibi yaptırımlar uygulayabilse de, üyelikten çıkarılma (ihraç) sendikanın disiplin yetkisine dayanarak verebileceği en ağır yaptırımdır (Sur, 2015). Sendikalara üyelerini çıkarma yetkisi verilmesindeki maksat kolektif sendika özgürlüğünü korumak, diğer bir deyişle bireysel sendika özgürlüğü ile kolektif sendika özgürlüğü arasında denge kurmaktır (Okur, 2013).

Üyelikten çıkarma nedenlerine tüzükte yer verilmesi mümkündür. Ancak tüzükte çıkarma nedenleri açıkça gösterilmişse söz konusu nedenlerin haklı sayılamayacağı yönünde itirazda bulunulamaz. Bununla birlikte bu türden hükümlerin yasal sınırlar içerisinde kalmak şartıyla demokratik esaslara uygun olması gerekir. Çıkarma nedenlerinin mutlaka sendika tüzüğünde yazılması da şart değildir. Tüzükte yazmasa dahi haklı ve önemli sebeplerin varlığı şartıyla üyelikten çıkarma kararı verilebilir. Sendikanın amaç ve ilkelerine aykırı davranmak, sendikayı kişisel çıkarları için kullanmak, sendika yöneticileri hakkında asılsız isnatlarda bulunmak, sendika sırlarını açığa vurmak, sendikanın geleceğini tehlikeye sokmak gibi eylemler sendika tüzüğünde yer verilmemiş olsa dahi üyelikten çıkarma bakımından haklı neden oluştururlar. Üyelikten çıkarma nedenlerinin haklı neden olup olmadığının tespiti güç olmakla birlikte üyeliği ret ve çıkarma sebepleri arasında teorik bir farklılık bulunmamaktadır. Ancak yine de haklı nedenlerin tümünün önceden tespit edilmesi mümkün değildir. Bu anlamda sendikanın, üyesinin sendikada kalmasına objektif olarak katlanamayacağı durumların haklı neden olarak görülmesi yerinde olacaktır (Okur, 2013).

Kamu görevlisinin sendikadan çıkarılması hususundaki karar, sendikanın en üst yetkili organı olan genel kurula tanınmıştır. Bunun sonucu olarak genel kurulun usulüne uygun olarak toplantıya çağrılmadığı yahut toplanmadı̆̆ olacaktır. Sendika disiplin kurulu tarafından üye kamu görevlisinin çıkarılması yönünde teklifte bulunulsa dahi bu kararı uygulayacak olan genel kuruldur (Uçkan, 2013) ve genel kurulun bu yetkisini başka bir organa devri mümkün değildir (Esener ve Gümrükçü, 2014). Kolektif sendika özgürlügüüün korunması önemli olmakla birlikte sendika üyesinin sendikada kalma hakkının ve sendikaların işleyişinin demokratik ilkelere uygunluğunun bir gereği olarak ihraç edilecek üyeye kendini savunma hakkı tanınmalı ve üyenin bu hakkı kısitlanmamalıdır (Şahlanan, 1980). Üyelikten çıkarmaya yönelik genel kurul kararının çıkarılana ve işverene yazı ile bildirilmek zorundadır. 
Ancak, unutulmamalıdır ki nasıl kolektif sendika özgürlüğü kapsamında sendikanın üyesini ihraç etme hakkı varsa; sendika üyesinin de sendika da üye olarak kalma hakkı vardır. Üyenin, haksız ve keyfi çıkarmalara karşı korunması bireysel sendika özgürlüğünün gereğidir(Okur, 2014). Sendikanın ihraç kararı hukuka uygun olmalıdır. Haklı bir sebebe dayanmayan ihraç kararları karşısında üyenin korunması için çıkarılma kararının yargı denetimine tabi tutulması öngörülmüştür (Aktay, Arıcı ve Kaplan, 2009). Bunun sonucu olarak çıkarma kararına karşı üyenin itiraz hakkı bulunmaktadır. Ancak buna ilişkin itiraz süresi 15 gün olup, bu süre hak düşürücü süre niteliğindedir (Esener ve Gümrükçüoğlu, 2014). Görevli mahkeme ise iş mahkemesidir. Mahkemenin karar verme süresi 2 ay olup, mahkeme karar verinceye kadar kamu görevlisinin sendika üyeliği devam eder. Mahkemenin itirazda bulunan kamu görevlisini haklı bulması ihraç kararının iptali anlamına gelir ve kamu görevlisinin sendika üyeliğini sürdürmesi anlamında herhangi bir engel kalmaz (Uçkan, 2013). Diğer bir deyişle sendika üyesinin üyeliği hiç sona ermemiş gibi kesinti söz konusu olmaksızın devam eder.

\section{Sonuç}

İşçiler açısından, çok daha eski bir hak mücadelesinin konusu olarak sendikal hakların tartışmasız bir biçimde tanındığı ve yasal olarak bu hakkın kullanımının önündeki engellerin kaldırılması anlayışının kanun koyucu tarafından da kabul edildiği açıktır. Bununla birlikte gelinen nokta Türkiye'nin taraf olduğu uluslararası sözleşmelerin gerekliliklerini tam olarak karşılamamaktadır. Özellikle kamu görevlisi sendikalarına üye olamayacaklara ilişkin yasaklar son derece geniş tutulmuş olup uluslararası denetim organlarınca da eleştiriye uğramaktadır. Her ne kadar AİHM kararları doğrultusunda Anayasa Mahkemesi kararlarıyla kamu görevlisi sendikalarına üye olamayacaklara yönelik 4688 sayılı kanundaki yasak kişiler azaltıldıysa da henüz imzalanıp iç hukuk haline getirilen uluslararası sözleşmelere uygun değildir.

\section{Kaynakça}

Aktay N. A./Arıcı K/Senyen Kaplan E. T., (2009). İ̧̧ Hukuku, Seçkin Yayınevi, Genişletilmiş 3. Bask1, Ankara .

Aktay N., Kamu Görevlileri Sendikaları ve Toplu Görüşme Esasları, (1998). Mercek, Nisan, 44-52.

Aktay N., (1993). Sendika Hakkı Uluslararası Dayanakları Bakımından Eleştirel Bir Yaklaşımla Türk Hukukunda Sendika Hakkı ve İlgili Belgeler, Kamu-Işs, Ankara.

AYM, T.10.4.2013, E.2013/21, K.2013/57.

AYM., T. 30.09.2015, E. 2015/62, K, 2015/84.

AYM., T.25.6.2009, E.2006/94, K.2006/92.

Esener T./Gümrükçüoğlu Y. B.,(2014). Sendika Hukuku, Vedat Kitapçılık, İstanbul.

Gerek N., (2003). Türkiye'de Memur Sendikacılığının Dünü ve Bugünü, Legal İş Hukuku Dergisi, Temmuz, 1655-1662

Gülmez M., (2014) Sendika Kararına Uyarak Toplu Eyleme Katılma 'Disiplin Suçu' Değil 'Mazeret'tir Danıştay İdari Dava Daireleri Kurulu Kararı Karar İncelemesi, Çalışma ve Toplum. 41(2), 191-204.

Gülmez M.,(2005). Sendikal Haklarda Uluslararası Hukuka ve Avrupa Birliği'ne Uyum Sorunu, Belediye-İş Yayınları, Ankara.

Günay C. İ., (2008). İş ve Sosyal Güvenlik Hukuku Dersleri, Yetkin Yayınları, Ankara.

Işıkl1 A.,(1996). İş Hukuku, 2. Baskı, İmaj Yayınevi, Ankara.

Kaboğlu İ. Ö.,(2001). Ekonomik Sosyal ve Kültürel Haklar, Anayasa Hukuku Kurultayı, TBB Yayınları, Ankara. 
Kutal M., (2006). ILO Uzmanlar Komitesi Raporunda (2005)Türk Mevzuatının 87 ve 98 Sayılı Sözleşmeler Karşısındaki Durumu, Sicil, 1 (1), 89-98.

Kutal M., (2007). Uluslararası Çalışma Normları Karşısında 4688 sayılı Kamu Görevlileri Sendikaları Kanunu, Sicil, Eylül. İstanbul.

Okur Z., (2013)., 6356 Sayılı Sendikalar ve Toplu İş Sözleşmesi Kanunu Bakımından Sendika Üyeliğinin Kazanılması ve Sona Ermesi, Çalışma ve Toplum,.39 (4). 69-110.

Sur M., (2015)., İ̧̧ Hukuku Toplu Illişkiler, Turhan Kitabevi, Ankara.

Sümer H. H., (2015). İş Hukuku, Mimoza Yayınevi, Konya.

Şahlanan F., (1980). Sendikaların İşleyişinin Demokratik İlkelere Uygunluğu, İstanbul Üniversitesi Hukuk Fakültesi Yayınları, İstanbul.

Tosun S., (2011). 87, 98, 151 Sayılı ILO Sözleşmelerine Göre Kamu Görevlilerinin Sendikal Hakları, TÜHIS İş Hukuku ve İktisat Dergisi, 23 (5-6),76-87.

Tuğ A., (1992). Sendikalar Hukuku, Yetkin Yayınları, Ankara.

Tuncay A. C., (1975). İşçi Sendikası Üyeliğinin Kazanılması ve Sona Ermesi, Fakülteler Matbaası, İstanbul.

Tuncay A. C./Savaş F. B. (2013)., Toplu İş Hukuku, 3. Bası, Beta Yayınevi, İstanbul.

Uçkan B., (2013). 4688 Sayılı Kamu Görevlileri Sendikaları ve Toplu Sözleşme Kanunu Çerçevesinde Türkiye'de Kamu Görevlileri Sendikacılı̆̆ı, Legal Yayıncılık, İstanbul.

Y.9.H.D., T.31.10.2006, E.28890, K.28763.

Yılmazer H./Dallı E./Arpad B., .(1962). Batıda Toplu Sözleşme ve Basın Sendikaları, İstanbul Gazeteciler Sendikası Yayınları, İstanbul. 